\title{
The influence of paraproteinaemia on the Technicon automated platelet counter
}

\author{
P. C. HALL AND R. M. IBBOTSON \\ From the Department of Haematology, The London Hospital, London
}

SYNOPSIS In five patients whose serum contained a paraprotein it has been shown that platelet counts obtained using the Technicon AutoCounter are much too high. In two patients with IgG gammopathy the error is caused by some factor in the red cells lysed by the diluent solution $2 \mathrm{M}$ urea. In three patients with IgM gammopathy spurious platelet counts were produced by plateletpoor plasma when diluted with $2 \mathrm{M}$ urea. It is recommended that at the present time no patient known to have a paraprotein should have platelet counts performed on the AutoCounter.

The Technicon AutoCounter has an optical system which detects light impulses from particles illuminated in a flow cell. The light pulses are focused on a photomultiplier tube where they are converted to electrical pulses. An electrical counting device integrates these pulses into peaks which are displayed on a strip chart recorder. For the purposes of platelet counting, the machine samples whole blood which is then diluted and haemolysed with $2 \mathrm{M}$ urea. The peak heights correspond to the number of platelets counted per unit time.

During the routine use of this instrument, several recordings were observed to be off the scale. In accordance with the manufacturers' manual, dilutions were made of each particular sample. The results obtained from the diluted samples in no way agreed with an assessment of platelet numbers in the respective peripheral blood films. These anomalous findings are the subject of this preliminary communication.

\section{Materials and Methods}

The Technicon AutoCounter was used. The samples Received for publication 24 April 1974. were initially haemolysed and diluted with 2 molar urea (Technicon Chemicals Co). Isoton (a modified Eagles solution) is supplied by Coulter Electronics Ltd.

Immunoglobulin assays were carried out on ID Agar plates at pH 8.2 after the method of Mancini, Carbonara, and Heremans (1965).

Four ml of blood was collected by a clean venepuncture into tubes containing $4 \mathrm{mg} \mathrm{K}_{2}$ EDTA. Where indicated platelet-rich plasma was obtained from this sample by centrifuging for 10 minutes at $100 \mathrm{~g}$. Platelet-poor plasma was separated by centrifuging for 30 minutes at $2000 \mathrm{~g}$.

Platelets were counted visually by phase contrast using an improved Neubauer chamber with diluting fluid consisting of $1 \%$ ammonium oxalate (Dacie and Lewis, 1970).

\section{Results}

During a six-month survey five patients were found whose platelet counts on the AutoCounter differed significantly from the appearances on film. Rowan, Allan, and Prescott (1972) suggested that the presence of paraprotein could interfere with auto-

\begin{tabular}{|c|c|c|c|c|}
\hline \multirow[t]{2}{*}{ Patient } & \multirow[t]{2}{*}{ Whole Blood } & \multirow{2}{*}{$\begin{array}{l}\text { Whole Blood Counted after } \\
\text { Dilution } 1: 3 \text { and Count } \\
\text { Corrected for Dilution }\end{array}$} & \multicolumn{2}{|c|}{ Platelet Count after Correction for PCV } \\
\hline & & & Platelet-rich Plasma & Platelet-poor Plasma \\
\hline $\begin{array}{l}\text { J.A. } \\
\text { W.H. } \\
\text { J.H. } \\
\text { J.W. } \\
\text { L.L. }\end{array}$ & $\begin{array}{r}600000 \\
>750000 \\
>750000 \\
>750000 \\
>750000\end{array}$ & $\begin{array}{r}- \\
1020000 \\
750000 \\
330000 \\
435000\end{array}$ & $\begin{array}{l}360000 \\
750000 \\
570000 \\
225000 \\
100000\end{array}$ & $\begin{array}{r}450000 \\
750000 \\
510000 \\
0 \\
0\end{array}$ \\
\hline
\end{tabular}

Table I Platelet count by Autocounter 


\begin{tabular}{|c|c|c|c|c|}
\hline \multirow[t]{2}{*}{ Patient } & \multirow[t]{2}{*}{ Whole Blood } & \multicolumn{3}{|c|}{ Platelet Count after Correction for PCV } \\
\hline & & Using Platelet-rich Plasma & Using Platelet-poor Plasma & $\vec{\nabla}$ \\
\hline $\begin{array}{l}\text { J.A. } \\
\text { W.H. } \\
\text { J.H. } \\
\text { J.W. } \\
\text { L.L. }\end{array}$ & $\begin{array}{r}22000 \\
470000 \\
93000 \\
220000 \\
67000\end{array}$ & $\begin{array}{r}25000 \\
600000 \\
140000 \\
189000 \\
81000\end{array}$ & $\begin{array}{l}0 \\
0 \\
0 \\
0 \\
0\end{array}$ & $\begin{array}{l}\overrightarrow{\bar{O}} \\
\frac{\bar{c}}{\overline{0}} \\
\frac{\bar{\sigma}}{\overline{0}}\end{array}$ \\
\hline
\end{tabular}

Table II Visual platelet count ${ }^{1}$

${ }^{1}$ Results expressed per $\mu 1$ whole blood

mated platelet counting, and in all cases a monoclonal gammopathy was shown to be present.

Platelet-rich plasma was prepared by slow speed centrifugation and the samples processed through the AutoCounter. In two cases, J.W. and L.L., the machine counts of platelet-rich plasma (table I) agreed with the visual counts performed on the same samples (table II). However, the platelet counts on cases J.A., W.H., and J.H. showed little comparison.

Platelet-poor plasma prepared by high speed centrifugation, when processed through the AutoCounter, resulted in the generation of a platelet count in cases J.A., W.H., and J.H. Examination by microscopy of all platelet-poor specimens confirmed that they were particle free. This was substantiated by submitting the samples to the AutoCounter again after using Isoton as the diluent with the result that zero counts were produced.

\section{Discussion}

Rowan et al (1972) postulated that red cell stroma, when coated with the abnormal protein, could interfere with automated platelet counting. The results in two cases, J.W. and L.L., both with an IgG paraprotein (table III), supported this hypothesis as machine counts of platelet-rich plasma compared favourably with visual counts. Thus in these two cases the removal of red cells by prior centrifugation appeared to prevent interference with counting whereas haemolysis by the working reagent $2 \mathrm{M}$ urea failed to do so.

However, the counts of platelet-rich plasma on cases J.A., W.H., and J.M. when compared with visual counts did not show this correction. Plateletpoor plasma from these patients when processed

\begin{tabular}{|c|c|c|}
\hline Patient & $\begin{array}{l}\text { Monoclonal Protein } \\
(\mathrm{mg} / 100 \mathrm{ml})\end{array}$ & $\begin{array}{l}\text { Normal Range } \\
(\mathrm{mg} / 100 \mathrm{ml})\end{array}$ \\
\hline $\begin{array}{l}\text { J.A. } \\
\text { W.H. } \\
\text { J.H. } \\
\text { J.W. } \\
\text { L.L. }\end{array}$ & $\left.\begin{array}{l}1880 \\
1800 \\
2880 \\
2200 \\
2100\end{array}\right\}$ IgM & $\begin{array}{c}50-110 \\
880-1500\end{array}$ \\
\hline
\end{tabular}

Table III Protein abnormalities in patients studied

still resulted in the generation of a platelet count. In $\overrightarrow{0}$ these cases the paraprotein was a macroglobulin.

Examination by microscopy and the use of Isoton as diluent in the AutoCounter confirmed that thes platelet-poor plasma was particle free. Red cello stroma could not be incriminated as generating the platelet count. Our work suggests that there is $\frac{\mathbb{Q}}{\AA}$ reaction between the abnormal protein and the $\vec{T}$ haemolysing agent. So far we have been unable to 3 characterize this reaction but postulate that $\operatorname{IgM}_{\supset}$ molecules are aggregating, thus providing a secondaryọ light source.

From our experience with the AutoCounter weo consider that patients with monoclonal gammopathies: should have platelet counts performed manually. If the count is brought on to the scale by the methodo of dilution (table I) considerable error is likely to be introduced.

\section{References}

Mancini, G., Carbonara, A. O., and Heremans, J. F. (1965). Im N munochemical quantitation of antigens by single radial immunodiffusion. Immunochemistry, 2, 235-254.

Dacie, J. V., and Lewis, S. M. (1970). In Practical Haematology, 4th ed., p. 70. Churchill Livingstone, Edinburgh and London.

Rowan, R. M., Allan, W., and Prescott, R. J. (1972). Evaluation of ano automatic platelet counting system utilizing whole blood. $J$. clin. Path., 25, 218-226. 